\title{
Comparative Analysis of Underground \& Underwater Tunnel
}

\author{
Nandolia Usama ${ }^{a}$, Shaikh Talib ${ }^{\mathrm{a}}$, Shaikh Abdull Alim ${ }^{\mathrm{a}}$, Shaikh Mohammed Shezad ${ }^{\mathrm{a}}$, Prof. Manjari Bhattacharya ${ }^{\mathrm{b}}$, \\ * a Student Department of Civil Engineering, Rizvi College of Engineering, Mumbai, Maharashtra, India. \\ * brofessor, Department of Civil Engineering, Rizvi College of Engineering, Mumbai, Maharashtra, India.
}

\begin{abstract}
With the urban population increasing, conurbation is getting more and more crowed, traffic jam happens everywhere. In this case, utilization of the underground and underwater space has become an effective way to undertake this set of problems. Tunnel construction is one of the important infrastructure projects, which is vital for enhancing the transportation networks, especially in congested cities. This review project presents a framework for selecting the appropriate tunneling method and transportation network with respect to the induced ground surface settlements. Parameters which have significant influence on the ground surface settlement will also be discussed in this project. This paper will help the contractors, engineers and designer in selecting appropriate method and estimating the required cost and time for construction of a tunnel.
\end{abstract}

Keywords: Settlement, tunneling method, tunnel geometry, geological condition, parameters effecting tunnel.

\section{INTRODUCTION}

Tunnel construction for transport routes is becoming increasingly important worldwide. Transport is accelerated and optimum protection is provided for the environment and the landscape. Many tunnels are considered technological masterpieces and governments have honored tunnel engineers as heroes. Constructing a tunnel, however, is one of the most complex challenges in the field of civil engineering. Tunnels are attractive solutions for railways, roadways, public utilities and telecommunications.

Worldwide population is increasing rapidly so the need of rapid or quick transportation to counter this approximately 3/4th of earth floor which is under water is to be used. This give rise to construction of underwater tunnel. An underwater tunnel is a passage, gallery or roadway beneath a body of water. Underwater tunnels are used for highway traffics, rail road and subways to transport sewage, oils, gas or vehicles and also for military and civil defense purpose

Modern underwater tunneling begins by constructing an immersed tube within a pre-dug trench on the river or sea floor, to do this pre-fabricated sections of steel and concrete tube are floated into position and strategically sunk into the trench. Immersed tunneling is an art of guiding the great natural force, the water, to do Engineering works: "guiding" buoyancy for transportation, "guiding" water weights for immersion, and "guiding" hydrostatic pressure for connection.

\section{LIMITATION EXISTING SYSTEM}

1) Immersed tunnels are often partly exposed (usually with some rock armour and natural siltation) on the river/sea bed, risking a sunken ship/anchor strike.

2) Direct contact with water necessitates careful waterproofing design around the joints.

3) The segmental approach requires careful design of the connections, where longitudinal effects and forces must be transferred across.

4) Environmental impact of tube and underwater embankment on existing channel/sea bed.

\section{SCOPE AND OBJECTIVE}

\section{SCOPE:}

1. Due to shortage of land and rapidly growing traffic and population, various underwater tunneling construction techniques should be implemented.

2. As underwater tunnel have shorter routes than bridges and roadways, its saves our important time.

3. Different materials such as oils, gas and drinking water can be simultaneously transported along with the traffic route.

4. By using advanced technologies transparent tube can be built which gives very aesthetic and attractive view for passengers and tourist.

5. Therefore making the overall project cost effective.

\section{OBJECTIVE:}

Tunnels are underground passages used for transportation. They could be used for carrying freights and passengers, water, sewage, etc. Tunnels are more economical than open cuts beyond certain depths. Tunnels avoid disturbing or interfering with surface life and traffic during construction. Tunnels prove to be cheaper than bridges or open cuts to carry public utility services like water, sewer and gas. Feasibility of these constructions in natural materials, such as rock and soil, causes the geological conditions to play a major role in their stability. Aspects of major importance and that is decisive for the feasibility of a tunnel project is geological conditions, construction time and costs. The objective of this lesson is to provide the general aspects of importance in tunnels, their types and methods of tunnelling. 


\section{LITERATURE REVIEW}

1) Douglas Allenby \& John W.T. Ropkins,(2006), Creating underground space at Shallow depth beneath our cities using jacked box tunneling,: This paper describes the jack box tunnel method with example, its use and detailed about the sensitivity. Jack box tunnel is a method of construction that enables Engineers to create underground space at shallow depth in a manner that avoids disruption of valuable infrastructure and reduces impact on environment.

2) Kamaladdin Edalat \& Mohammad Javad Vahdatirad, (2010), ChoosingTBM for Tabriz subway using multi criteria method: Case study of Tabriz Urban Railway Line is presented in this paper.The TBM model is used for construction of tunnel. Two kinds of TBM model suggested.EPH (Earth Pressure Balance), SS (Slurry Shield) are used and compared for various parametric, environment, technical, and economical effect on the project.

3) Ford, Charles (1997): Immersed tunnel techniques 2. Proceedings of the international conference organized by the Institution of Civil Engineers in association with the Institution of Engineers of Ireland and held in Cork, Ireland on 23-24 April 1997. Thomas Telford, London (United Kingdom), ISBN 9780727726049, pp. 368.

4) Mouratidis, (2008), The "Cut-and-Cover" and "Cover and-Cut" Techniques in Highway Engineering: The use of "Cut \& Cover" and "Cover and Cut" methods are studied in this paper for construction of underground tunnels or subways. In this paper, the overview of both the methods is presented which includes describing main features, advantages and field applications.

5) Mariagrazia Di Pilato; Anna Feriani; Federico Perotti (17 March 2008). "Numerical models for the dynamic response of submerged floating tunnels under seismic loading". Earthquake Engineering \& Structural Dynamics, Volume 37 Issue 9, pages 1203-1222. Archived from the original on 5 January 2013.

\section{v. THEORETICAL STUDY OF TUNNELS}

\section{a. BASICS OF TUNNELS}

Tunnel is an artificially constructed underground passage to by- pass obstacles safely without disturbing the over burden. Tunnels are created by the process of excavation. Ratio of length to width, in a tunnel, should always be at least in 2: 1. Tunnelling is desirable when rapid transport facilities are required which need to avoid acquisition of land for roads.

\section{b. PHYSICS OF TUNNELLING}

1. Tension, which expands, or pulls on, material

2. Compression, which shortens, or squeezes material

3. Shearing, which causes parts of a material to slide past one another in opposite directions

4. Torsion, which twists a material

\section{c. TUNNEL DESIGN CRITERIA}

Tunnelling requires proper design. Every tunnel will have its own geometry, design, alignment, and construction methods. The tunnel design criteria include the following aspects:

1. Spatial Requirements;

2. Alignment;

3. Underground Stations;

4. Fire Life Safety; and Tunnel Systems and Operation.

5. Every tunnel should have its own Horizontal and Vertical Alignment, Tunnel Ventilation, Tunnel Lighting, Electrical and Safety Equipment, Tunnel Drainage, Fire Life Safety, and Security.

\section{d. INVESTIGATIONS FOR TUNNELLING}

1. Geological Investigations -relation between bed rock and top soil.

2. Morphology, Petrology, Stratigraphy

3. Electrical Resistivity Methods - positions of weak zones -faults, folds and shear zones.

\section{DEVELOPMENT OF TUNNEL AND CONSTRUCTION METHODS}

\section{- UNDERGROUND TUNNEL}

a. Cut and Cover Method of Tunnel Construction

Cut and cover method of tunnel construction is generally used to build shallow tunnels. In this method, a trench is cut in the soil and it is covered by some support which can be capable of bearing load on it.

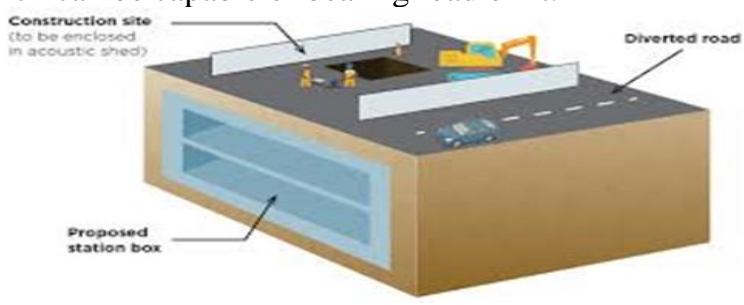

b. Bored Tunnel Method

Bored tunnel method is modern technology. In this case, tunnel boring machines are used which automatically work and makes the entire tunneling process easier. It is also quicker process and good method to build tunnel in high traffic areas.

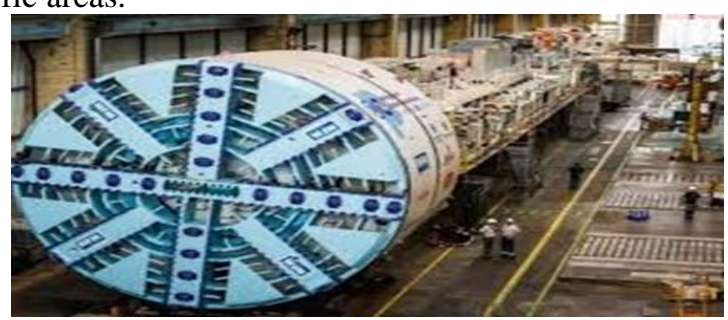

c. Clay Kicking Method of Tunnel Construction

This method is used for strong clayey soil conditions. This is an old method and used for small works like sewage pipes installations etc. In this method, a hole is excavated into the ground and after some depth tunnel is excavated which is done by the clay kicker which lies 0n a plank at 
45o angle. An excavating tool is provided under clay kicker foot.

\section{d. Shaft Method of Tunnel Construction}

In this method tunnel is constructed at greater depth from the ground surface. The shaft is built up to the depth where tunnel is required.

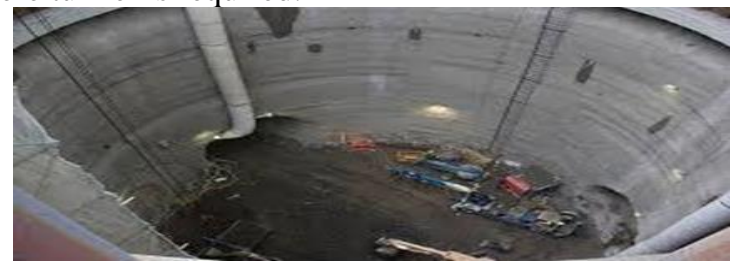

e. Pipe Jacking Method of Tunnel Construction

Pipe jacking method is used to construct tunnels under existing structures like road ways, railways etc. In this method, specially made pipes are driven into underground using hydraulic jacks. Maximum size of 3.2-meter diameter is allowed for tunnels

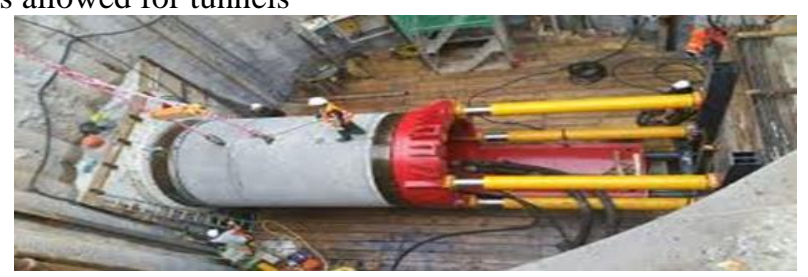

- UNDERWATER TUNNEL

\section{A. Immersed tube tunnel}

An immersed tube tunnel is made up of many prefabricated tubes constructed on land, which are then floated and moved to its dredged location by romorks in the sea. The tubes are lowered and connected with each other underwater.

\section{STEEL SHELL TUNNELS}

\section{a. SINGLE STEEL SHELL}

A single steel shell element has an external steel shell fabricated typically from $10 \mathrm{~mm}$ steel plate. This does not have to be the traditional circular steel tunnel shape as can be seen in Figure. The steel shell provides strength and water tightness.

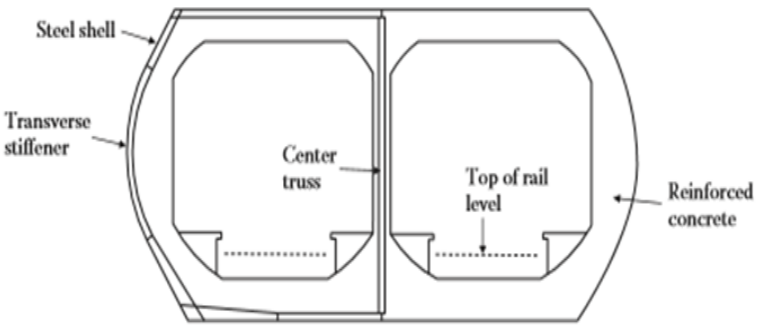

\section{b. DOUBLE STEEL SHELL}

The cross section of a double steel shell has two steel skins. There is an inner steel shell, which is thinner than the steel shell of a single shell tunnel and typically $8 \mathrm{~mm}$ thick. This outer form plate is slightly thinner than the inner shell at typically $6 \mathrm{~mm}$.

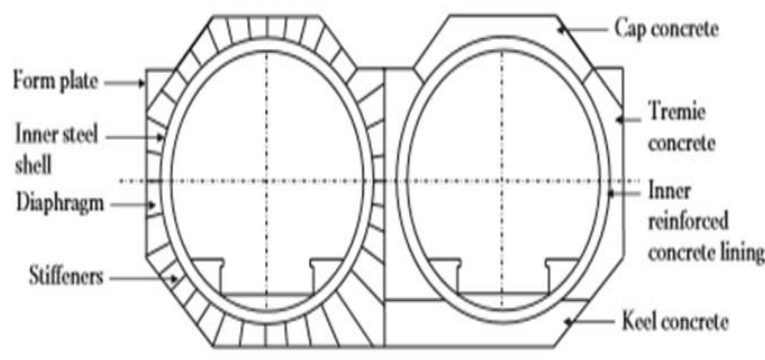

\section{CONCRETE TUNNELS}

a. MONOLITHIC

\section{CONSTRUCTION}

The first, simplest and most straightforward of the concrete tunnel options is the monolithic element. Each tunnel element is a continuous structure that acts as a beam.

\section{b. SEGMENTAL CONCRETE ELEMENT CONSTRUCTION}

The segmental form concrete tunnel element was developed from the original monolithic tunnel element to avoid the need for an external waterproofing membrane.

\section{c. PRESTRESSED CONCRETE}

A variation of the monolithic reinforced concrete element is to prestress it with permanent longitudinal prestress. This form of tunnel element can have advantages in reducing the amount of longitudinal reinforcement and also the overall compressive stress it provides tends to close any cracks in the concrete, reducing the likelihood of leakage.

\section{d. COMPOSITE SANDWICH TUNNEL}

The use of steel-concrete composite sandwich construction is a more recent development that has mostly been promoted in Japan, although a lot of research and testing has also been carried out in the United Kingdom. The concrete is placed between the steel plates, so a very fluid self-compacting mix is required. Placing this concrete and ensuring sufficient compaction and complete filling of the void between the plates is one of the main challenges of this method.

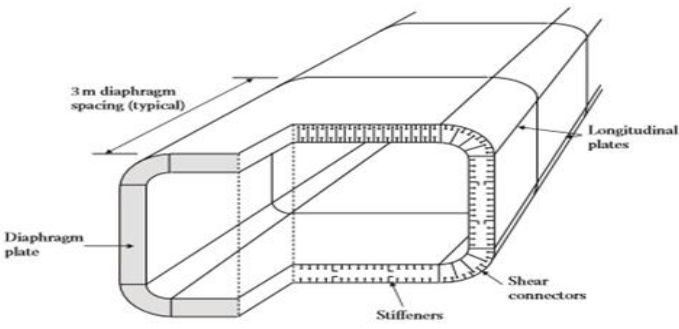

\section{B. Submerged Floating Tunnel}

A submerged floating tunnel (SFT), also known as submerged floating tube bridge (SFTB), suspended tunnel, or Archimedes bridge, is a proposed design for a tunnel that floats in water, supported by its buoyancy (specifically, 
by employing the hydrostatic thrust, or Archimedes' principle)

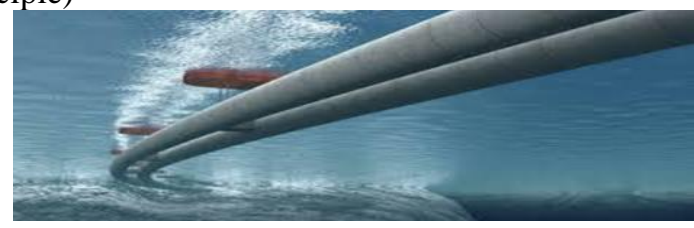

\section{HEALTH AND SAFETY, AND ENVIRONMENTAL IMPACT IN TUNNELING}

\section{a. OCCUPATIONAL HEALTH}

Occupational health is seldom allocated the priority it should be, given the number of days lost to ill health. The reasons for occupational health provision are two-fold:

- To address ill health due to work.

- To ensure fitness for work.

\section{b. WELFARE AND FIRST AID}

The provision of basic welfare in tunnels under construction is improving. Space for basic toilet and washing facilities is limited in small tunnels, but in larger tunnels there is enough space for toilet means of boiling water and heating food as part of the TBM equipment aids welfare and reduces the risk from improvised electrical installations. First aid provisions must be available to meet the requirements of the project in terms of shift working and remote working.et and washing facilities on the TBM or in the tunnel.

\section{c. EDUCATION, TRAINING AND COMPETENCE}

Large tunnelling projects may need to set up their own training facilities, for example Cross Rail in the UK set up its own 'Tunnelling Academy' to train the large number of workers required for this project.

All new employees in the industry should undergo comprehensive induction training. Site-specific training, even for experienced employees who are new to a site, is also necessary. Engineers and managers now undertake training in health and safety matters as part of their professional education and continuing professional development.

\section{d. FIRE, FLOOD RESCUE AND ESCAPE}

Among the most significant safety hazards of tunnelling, to which the workforce is exposed, are fire and smoke. Good housekeeping is another vital precaution in minimizing the buildup of flammable rubbish, which typically in tunnelling includes timber, plastic bottles, paper, discarded hoses and cables. All hydraulic systems should be well engineered.

\section{e. ENVIRONMENTAL IMPACT}

Environmental legislation is becoming stricter globally as awareness of potential impacts increases. At the same time, methods to manage impacts are becoming more sophisticated, and it is essential to understand the issues and how they can best be dealt with, whether as a planner, designer, constructor, or project sponsor. The production of an environmental impact assessment (EIA) is a standard requirement in most countries around the world and is used as a tool for ensuring impacts.

\section{f. TUNNEL APPROACHES}

The major impact of an immersed tunnel scheme generally occurs during construction when disturbance of the waterway and the banks is inevitable.. Often, the banks are environmentally sensitive, are recreational areas or protected wildlife areas, or are areas of outstanding landscape importance. In an estuary or tidal river location, constructing the approaches will almost certainly raise environmental issues relating to the intertidal mudflats.

\section{g. MARINE WORKS}

The main activity in the waterway itself is the excavation, and subsequent backfilling, of the trench for the tunnel. Placing of tunnel elements is relatively fast and causes no real disturbance to the environment. Dredging, by its very nature, stirs up the bed of the river, resulting in an increased amount of sediment in the river.

\section{h. FISHERIES}

Once a tunnel has been completed, there is no long-term effect on the movement of fish up and down the river. The one caveat to this is that if an impressed current cathodic protection system is installed, there is the potential for electric currents to disturb the fish, and this effect should not be overlooked.

\section{i. ALGAE \& WATER QUALITY}

At some tunnel sites there is the possibility of blooms of algae that can hinder construction. These can be a severe handicap to the construction process.

As discussed, changes to the water quality during construction can adversely affect the marine biology. Oxygen content and turbidity are factors affecting the quality of marine life and strict limits on the extent of any changes during construction must be imposed.

\begin{tabular}{ll}
\hline Parameter & \multicolumn{1}{c}{ Typical target values } \\
\hline Dissolved oxygen level to be & $5 \mathrm{mg} / \mathrm{L}$ (95 percentile) \\
maintained during construction & $3 \mathrm{mg} / \mathrm{L}$ absolute minimum \\
Turbidity limit & $<30$ to $50 \mathrm{FTU}$ \\
Suspended solids limit & $200 \mathrm{mg} / \mathrm{L}$ (95 percentile) \\
& $500 \mathrm{mg} / \mathrm{L}$ absolute maximum \\
\hline
\end{tabular}

\section{j. $\quad$ VISUAL ASPECTS \& AIR QUALITY}

A tunnel imposes far less visual intrusion on a waterway and the surrounding area than a bridge. Once completed it is often almost invisible, except from the air. These include service buildings, ventilation inlet and exhaust towers, the architectural appearance of the portals, and the type of approach structures.

The tunnel design needs to consider air pollution. Overall pollution from the traffic is not increased but that pollution is concentrated. If longitudinal ventilation is being used, then the pollution is concentrated around the Portals, 
whereas with transverse or semi-transverse ventilation the pollution is concentrated around the exhaust stack.

\section{GROUND MOVEMENTS AND MONITORING}

\section{- UNDERGROUND TUNNEL:-}

\section{a. GROUND DEFORMATION IN SOFT GROUND} AND ROCK:-

When tunnelling in hard ground (rock), ground movements are not normally a problem, except in squeezing ground conditions, and ground movements propagating up to the ground surface as a result of the excavation are unlikely unless the cover depth of the tunnel is relatively small, i.e. in portal areas, or where the groundwater in the overlying soft ground may be affected. In soft ground, however, displacements can occur due to a number of reasons and these are shown for a shield tunnel on Figure
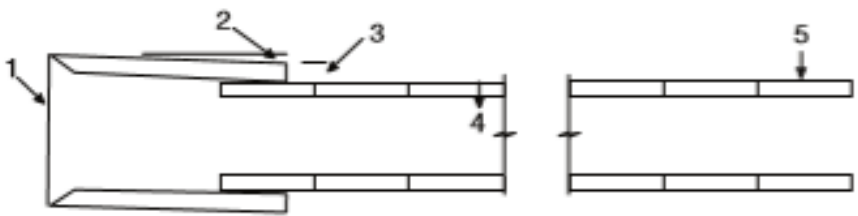

Component 1 is particularly important with open face tunnelling methods.

Component 2 can result if there is difficulty keeping the tunnelling shield on the correct alignment, or if there is a need to tilt the shield up slightly to prevent it from diving into the ground.

Component 3 can be minimized by immediate grouting of the void.

Component 4 is usually small compared to the other components once the lining ring is completed.

Component 5 can be important for soft clays, and results from the fact that the construction process changes the stress regime locally around the tunnel.

\section{b. HORIZONTAL DISPLACEMENTS:-}

From the point of view of damage to structures and services it is not only important to determine vertical displacements within the ground, but also the horizontal movements

$\mathrm{Sh}=\mathrm{Svy} / \mathrm{H}(7.9)$

Where $\mathrm{Sv}$ is the vertical ground displacement, $\mathrm{Sh}$ is the horizontal ground displacement and $\mathrm{y}$ is the transverse horizontal distance from the tunnel centerline.

\section{c. LONG-TERM SETTLEMENTS:-}

Long-term settlement is a phenomenon predominantly associated with fine grained soils and is associated with component 5 in Figure above

1. The tunnel acting as a drain

2. Time dependent distortion of the tunnel lining

3. Time dependent dissipation of excess pore water pressures due to grouting behind the lining or due to mitigation measures such as compensation grouting

4. Creep and secondary consolidation processes in soils
5. Time dependent closure of the grouted annular gap due to: bleeding and curing (hardening and shrinkage) of the grout, insufficient grout or loss of grout.

\section{d. GROUND IMPROVEMENT AND STABILIZATION TECHNIQUES:-}

This section describes a number of techniques that can be used to improve the stability of the ground to aid construction of the tunnel, and in soft ground to reduce/control ground displacements and hence mitigate the effects of the tunnelling operation on adjacent structures.

- $\quad$ Ground Freezing

- Lowering Of the Groundwater Table

- Grouting

\section{- UNDERWATER TUNNEL:-}

\section{a. SETTLEMENT:}

In a watercourse carrying a high sediment load, it is desirable to immerse the tunnel elements as soon after completion of dredging and trench cleaning as possible, and to perform the sand flow operation as quickly as possible after the elements have been immersed.

\section{b. RISK OF SEDIMENTATION:-}

Very important in planning the marine activities for forming the foundations to assess the risk of sedimentation and plan for monitoring and cleaning procedures, should it occur. If there is a risk of sedimentation, then exposure time between placing an element and under filling it should be minimized.

\section{c. BEHAVIOR IN SEISMIC CONDITIONS:-}

Sand foundations can perform satisfactorily under seismic load, provided some thought is given to the risks at the design stage. The issue to guard against is preventing liquefaction. This can be achieved by the selection of an appropriate grading or through stabilization. In highly active zones, a gravel or grouted gravel solution is more likely to give an appropriate solution.

\section{d. GROUND IMPROVEMENT:-}

Ground improvement may be required for a variety of reasons. Immersed tunnels are often built in the relatively poor fluvial or glacial deposits of rivers and estuaries, with sands and gravels often interspersed with layers of silt and clay. If the soils need to be improved, there are a number of recognized techniques that may be chosen:

- Granular replacement

- Stone columns

- Sand compaction piles (SCPs)

- $\quad$ Soil mixing 


\section{FOUNDATION OF TUNNELS}

\section{- UNDERGROUND TUNNEL}

a. EFFECT OF TUNNELLING ON EXISTING $\begin{array}{lll}\text { TUNNELS, BURIED UTILITIES AND } & \end{array}$

\section{FOUNDATIONS}

BURIED UTENSILS In addition to buildings, it is important not to forget about structures that lie beneath the ground surface, for example existing tunnels and buried utilities.

EXISTING TUNNELS In terms of the effects of tunnelling on existing tunnels, the overall philosophy, though, was to minimize the ground movements at source, i.e. using high specification EPB tunnelling machines, and to use a risk-based engineering assessment of the effect of the tunnelling works on the existing tunnels.
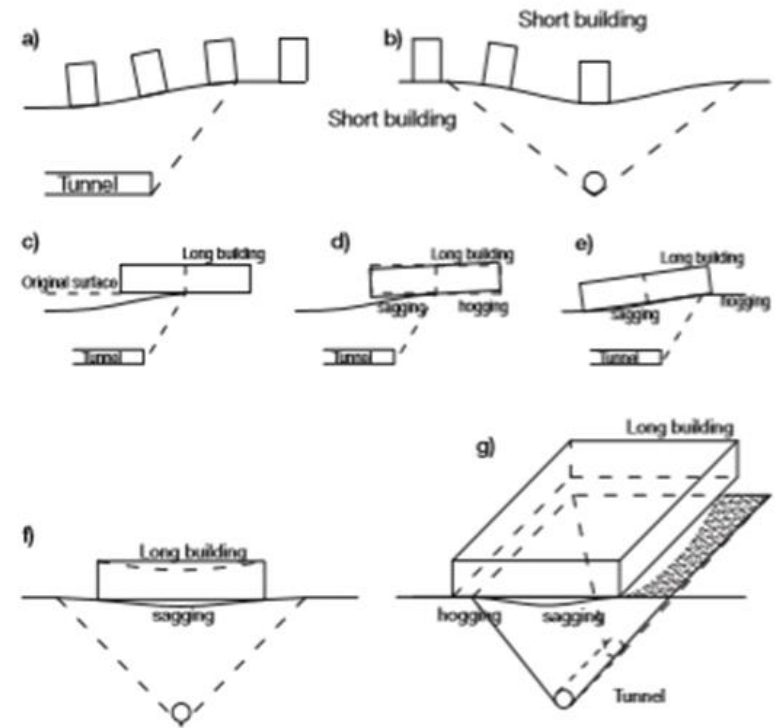

$15 \mathrm{~m}$ depth

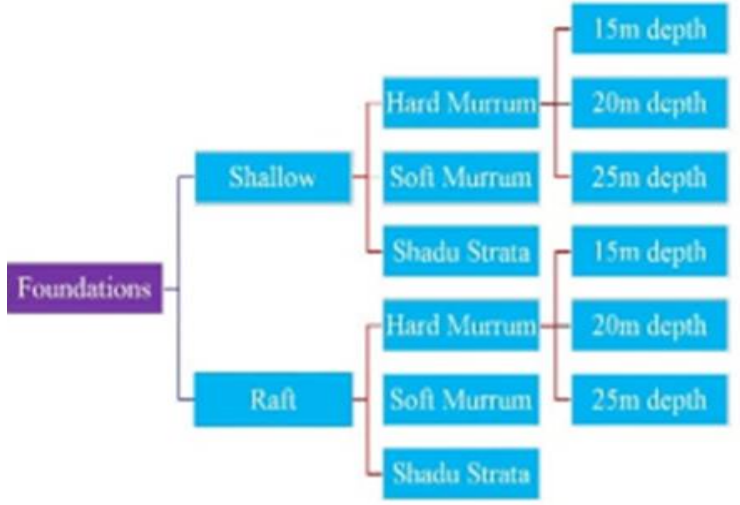

Figure: 4.13 flow chart for depth, some idealized modes of behaviour for short buildings and long buildings due to a tunnel construction.

\section{- UNDERWATER TUNNEL}

\section{A. SAND FOUNDATION LAYER}

Immersed tunnels are frequently located in poor ground conditions. The foundation of an immersed tunnel can be considered to be made up of two parts:
1. The foundation layer placed on the dredged surface immediately beneath the tunnel structure.

2. The deep foundations in the substrata below the level of the dredged trench.

There are two fundamental approaches that may be followed to form this bedding layer:

1. Place the tunnel elements in the trench onto temporary supports, under fill the space between the tunnel elements and the surface of the trench, and release the temporary support.

2. Lay a close tolerance foundation layer at the base of the tunnel trench that the tunnel elements can be placed directly onto.

\section{- METHODS:-}

\section{a. SAND JETTING METHOD}

With this technique, the tunnel element is temporarily supported above the bed of the trench. The sand is then injected into the space under the element. Original sand jetting equipment is shown diagrammatically. It was developed in the 1930s by Christiani and Nielsen, the Danish contractor that was instrumental in the development of concrete immersed tunnels.

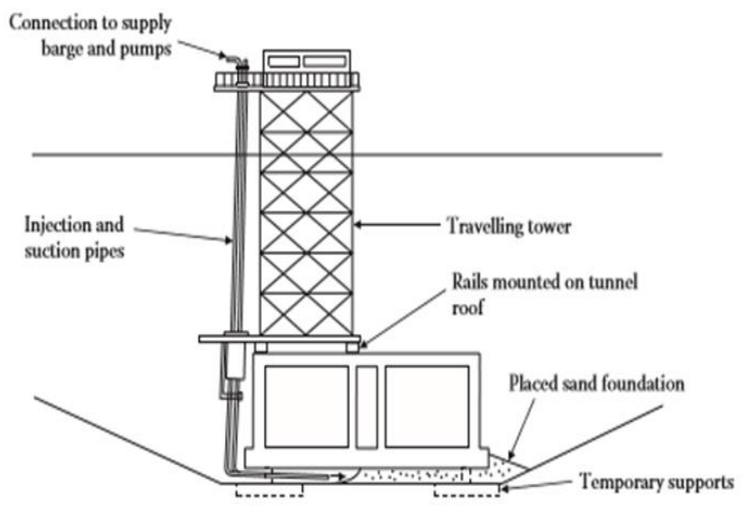

\section{b. SAND FLOW METHOD}

A new method was developed in which the sand/water mixture was pumped directly into the space under the tunnel through holes in the tunnel floor. This was called the sand flow method and has, subsequently, been widely adopted as the usual method of placing tunnel foundations.
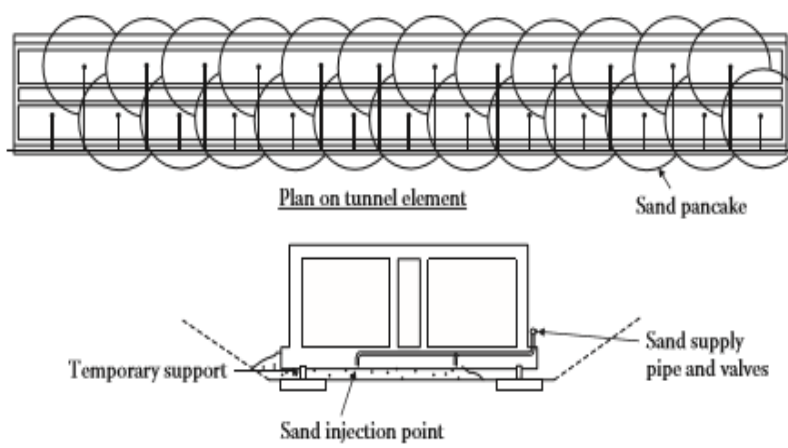


\section{B. GRAVEL FOUNDATION LAYERS}

Gravel bed foundations exhibit different characteristics than sand foundations. Gravel beds offer improved performance of foundations in seismic conditions. Although it is important to guard against shakedown effects, which may cause the gravel layer to compact, the gravel will not suffer liquefaction and can be used to relieve the buildup of excess water pressures in the substrata and reduce the risk of liquefaction \& types of gravel foundation is

- Underwater screeding frames

- Scrading

\section{ESTIMATION OF TUNNEL}

Before planning and estimating the cost of a tunnel, it is necessary to understand the different equipment and work methods that can be used to accomplish the job. Tunnel construction equipment may be divided into three main groups:

(a) Excavation equipment such as drills, jumbos, tunnelboring machines, road headers, and mucking machines;

(b) Tunnel haulage equipment such as front-end loaders, trains, and conveyors; and

(c) Service equipment and facilities such as ventilation and air conditioning, generators, hoists, and lights.

\section{- $\quad$ METHODS OF ESTIMATION}

1. Manual method

- Unit cost method

- Tunnel cost curve

2. With aid of computers

- COSTUN (SOFTWARE)

- STEPS INVOLVE IN MANUAL METHOD-

a. Obtain and study plans and specifications.

b. Inspect site.

c. Review aerial photographs, geological reports, and boring logs.

d. Tabulate quantity takeoffs.

e. Obtain quotes from suppliers, insurance and

bonding companies, and subcontractors.

f. Determine wage rates.

g. Prepare construction schedule.

h. Select excavation method.

i. Select equipment.

j. Estimate cost of equipment rental or purchase.

k. Determine crew size and makeup.

1. Estimate progress rates.

$\mathrm{m}$. Estimate cost of aboveground development.

n. Estimate cost of tunnel excavation supplies.

o. Estimate cost of tunnel excavation labor.

p. Estimate cost of support and lining supplies.

q. Estimate cost of plant.

r. Estimate cost of concrete-lining labor.

s. Estimate direct cost of other bid items.

t. Tabulate all direct costs.

u. Estimate indirect costs.

v. Estimate camp costs

w. Estimate escalation. x. Tabulate total estimated costs of project in format required by request for bid.

\section{- UNIT COST METHOD -}

The unit cost method of estimating tunnel costs is a wellaccepted simple technique for making preliminary or planning estimates. It relies on historical records of similar jobs. Basically, the estimator prepares quantity takeoffs for the tunnel and determines the unit cost of each item by comparison with other similar tunnels.

\section{- TUNNEL COST CURVE-}

One of the earliest reported developments to improve the reliability and reduce the time required for preliminary tunnel estimates was made by the California Department of Water Resources (1959). Preliminary estimates to aid in route selection led to the formulation of a family of "cost curves." Case histories were analyzed to determine the cost impact of all factors involved in tunneling.

They considered four major construction items affecting cost: excavation, support, dewatering, and lining. For each item, a family of cost curves was developed. Each curve represented a specified geological classification. The curves were plotted as item cost per foot of tunnel versus tunnel diameter.

\section{- COSTUN-SOFTWARE}

Costun was developed in 1973 by Harza Engineering Company under contract to the Federal Railroad Administration (FRA), U. S. Department of Transportation. Complete documentation of this program is contained in Report No. FRA-ORD\&D-74-16 (Wheby and Cikanek 1973). The report is available through the National Technical Information Service, Springfield, Virginia 22151. Permission by the FRA to use excerpts from this report is gratefully acknowledged.

The cost calculations were based on cost curves for different size tunnels and various geologic conditions developed using the COSTU' program. The method described herein allows the user to develop a more comprehensive and accurate estimate. It must be remembered, however, that the accuracy of any estimating method depends on the accuracy of the required input data.

\section{RESULT AND DISCUSSION}

\begin{tabular}{|c|c|c|c|}
\hline \multirow{2}{*}{\multicolumn{4}{|c|}{ METHODS }} \\
\hline & & & \\
\hline Method & $\begin{array}{l}\text { Convenience } \\
\text { \& utility }\end{array}$ & $\begin{array}{ll}\text { Drawback } & \& \\
\text { obstruction } & \end{array}$ & $\begin{array}{l}\text { Multipurpose } \\
\text { \&Existing } \\
\text { tunnels }\end{array}$ \\
\hline $\begin{array}{l}\text { DRILL } \\
\text { BLAST }\end{array}$ & $\begin{array}{l}\text { Very adaptable } \\
\text { and flexible } \\
\text { Short } \\
\text { mobilization } \\
\text { time } \\
\text { requirement. } \\
\text { Any required } \\
\text { shape tunnel } \\
\text { cross section is } \\
\text { possible. } \\
\text { Primary rock } \\
\text { support can be }\end{array}$ & $\begin{array}{l}\text { Safety of } \\
\text { workers is a } \\
\text { serious issue } \\
\text { Performance } \\
\text { rate of advance } \\
\text { excavation is } \\
\text { lower. } \\
\text { Total labor cost } \\
\text { is high. } \\
\text { Involvement of } \\
\text { hard and high } \\
\text { manual labor. }\end{array}$ & $\begin{array}{l}\text { Before } \\
\text { beginning the } \\
\text { use of tunnel } \\
\text { boring machine, } \\
\text { Drill and blast } \\
\text { method was the } \\
\text { only economic } \\
\text { way for the } \\
\text { construction of } \\
\text { tunnel }\end{array}$ \\
\hline
\end{tabular}




\begin{tabular}{|c|c|c|c|}
\hline & $\begin{array}{l}\text { installed Total } \\
\text { investment } \\
\text { cost is less } \\
\text { Tunnel shape } \\
\text { can be changed } \\
\text { along the drive } \\
\text { length. }\end{array}$ & $\begin{array}{l}\text { Low level of } \\
\text { automation and } \\
\text { mechanization } \\
\text { of tasks. }\end{array}$ & \\
\hline TBM & $\begin{array}{l}\text { Very high } \\
\text { performance } \\
\text { and low labor } \\
\text { costs. } \\
\text { High progress } \\
\text { rate, especially } \\
\text { in soft ground } \\
\text { soil. } \\
\text { Excellent cost } \\
\text { efficiency and } \\
\text { high } \\
\text { automation. } \\
\text { Level } \\
\text { Continuous } \\
\text { operation. } \\
\text { Less noise and } \\
\text { disturbance to } \\
\text { surrounding } \\
\text { structures. } \\
\text { Best way for } \\
\text { constructing } \\
\text { deep and long } \\
\text { tunnels. }\end{array}$ & $\begin{array}{l}\text { Limited } \\
\text { flexibility in } \\
\text { response to } \\
\text { extremes of } \\
\text { geologic } \\
\text { conditions. } \\
\text { High } \\
\text { investment } \\
\text { costs } \\
\text { require high } \\
\text { backup } \\
\text { systems. } \\
\text { TBM } \\
\text { mobilization } \\
\text { take } \\
\text { considerable } \\
\text { time. } \\
\text { Fixed circular } \\
\text { geometry and } \\
\text { tunnel diameter. } \\
\text { Longer } \\
\text { mobilization } \\
\text { time and higher } \\
\text { capital costs. }\end{array}$ & $\begin{array}{l}\text { Kuala Lumpur, } \\
\text { SMART 2007 } \\
\text { US\$514M } \\
\text { Multifunctional } \\
\text { include storm } \\
\text { water } \\
\\
\text { Channel Tunnel } \\
\text { MB 12.3Bn } \\
\text { Utilities and } \\
\text { light rail on } \\
\text { lower deck }\end{array}$ \\
\hline JACKED BOX & $\begin{array}{l}\text { Economical } \\
\text { and Better } \\
\text { quality control. } \\
\text { Time of } \\
\text { completion is } \\
\text { less } \\
\text { Saving in man } \\
\text { power \& } \\
\text { Machinery. } \\
\text { No } \\
\text { involvement of } \\
\text { crane \& heavy } \\
\text { equipment } \\
\text { Less } \\
\text { involvement of } \\
\text { other } \\
\text { Departments. }\end{array}$ & $\begin{array}{l}\text { Needs trained } \\
\text { staff \&skilled } \\
\text { supervision. } \\
\text { Imposition of } \\
\text { caution order } \\
\text { exists for a } \\
\text { longer period. } \\
\text { No scope of the } \\
\text { night working. } \\
\text { Once the } \\
\text { vertical \& the } \\
\text { lateral } \\
\text { alignment of } \\
\text { box disturbed it } \\
\text { becomes almost } \\
\text { impossible to } \\
\text { rectify it. }\end{array}$ & $\begin{array}{l}\text { mainly for } \\
\text { road, rail, } \\
\text { pedestrian, car } \\
\text { parking, office } \\
\text { access, } \\
\text { machinery } \\
\text { rooms, archive } \\
\text { and } \\
\text { storage }\end{array}$ \\
\hline $\begin{array}{l}\text { CUT } \quad \& \\
\text { COVER }\end{array}$ & $\begin{array}{l}\text { Preservation of } \\
\text { the } \\
\text { environment. } \\
\text { Safe initiation } \\
\text { and } \\
\text { completion of } \\
\text { highway } \\
\text { tunnels. } \\
\text { Safe work } \\
\text { progress in } \\
\text { unstable weak } \\
\text { ground. } \\
\text { May applied as } \\
\text { sequential } \\
\text { construction in } \\
\text { case of most } \\
\text { adverse getechnical } \\
\text { geoteche } \\
\text { conditions. } \\
\text { Cheaper and } \\
\text { more practical } \\
\text { than other } \\
\text { underground } \\
\text { tunneling. } \\
\text { Small risk, } \\
\text { relative } \\
\text { other to }\end{array}$ & $\begin{array}{l}\text { Not suitable for } \\
\text { very deep } \\
\text { excavations. } \\
\text { More dust and } \\
\text { noise impact } \\
\text { may arise. } \\
\text { Cause } \\
\text { interference } \\
\text { with traffic and } \\
\text { other urban } \\
\text { activities. }\end{array}$ & $\begin{array}{l}\text { LDB201 } \\
\text { Chau tau tunnel } \\
1.4 \mathrm{~km} \\
\text { Use only for the } \\
\text { construction of } \\
\text { several shallow } \\
\text { depth tunnels } \\
\text { such as rapid } \\
\text { transit tunnels, } \\
\text { vehicular } \\
\text { tunnels and } \\
\text { sewer tunnels. }\end{array}$ \\
\hline
\end{tabular}

\begin{tabular}{|c|c|c|c|}
\hline & $\begin{array}{l}\text { construction } \\
\text { techniques. }\end{array}$ & & \\
\hline $\begin{array}{l}\text { IMMERSSED } \\
\text { TUBE } \\
\text { TUNNEL }\end{array}$ & $\begin{array}{l}\text { Most Suitable } \\
\text { for short length } \\
\text { as compare to } \\
\text { other tunnels. } \\
\text { Dredged } \\
\text { material was } \\
\text { used to create } \\
\text { the artificial } \\
\text { islands. } \\
\text { Suitable for } \\
\text { poor river bed } \\
\text { and geological } \\
\text { condition. }\end{array}$ & $\begin{array}{l}\text { Partly exposed } \\
\text { on river bed } \\
\text { risking a } \\
\text { sunken ship and } \\
\text { anchor strike. } \\
\text { Demanding } \\
\text { high } \\
\text { technologized } \\
\text { water proofing. } \\
\text { Impact of } \\
\text { tunnel element } \\
\text { and embankment on } \\
\text { emannel or sea } \\
\text { bed. } \\
\text { Careful design } \\
\text { connection. }\end{array}$ & $\begin{array}{l}\text { Öresund } \\
\text { Crossing, } \\
\text { Denmark (Dual } \\
\text { two lane plus } \\
\text { Rail)1998, } \\
\text { construction } \\
\text { period } 7 \text { years, } \\
\text { 3.5km and } \\
\text { multimodal } \\
\\
\text { Thomassen } \\
\text { Tunnel, } \\
\text { Netherlands. } \\
\text { (Dual Three } \\
\text { Lane) 2004 } \\
\text { Construction } \\
\text { period 5 year , } \\
\text { 1km } \\
\text { DFL } \\
350,000,000\end{array}$ \\
\hline $\begin{array}{l}\text { SUBMERGED } \\
\text { FLOATING } \\
\text { TUNNEL }\end{array}$ & $\begin{array}{l}\text { Allows } \\
\text { construction of } \\
\text { tunnel in } \\
\text { extremely deep } \\
\text { water. } \\
\text { Any type of } \\
\text { cross section } \\
\text { can be made. } \\
\text { No obstruction } \\
\text { to navigational } \\
\text { routes. } \\
\text { Less harmful } \\
\text { effects on } \\
\text { aquatic life. } \\
\text { Tremendous } \\
\text { speed for trains } \\
\text { obtained by } \\
\text { creating } \\
\text { vacuum inside } \\
\text { tunnel. }\end{array}$ & $\begin{array}{l}\text { Cost of project } \\
\text { is too high } \\
\text { It is difficult to } \\
\text { rescue people if } \\
\text { any fire or } \\
\text { hazardous thing } \\
\text { happen. } \\
\text { No stoppage of } \\
\text { train or } \\
\text { vehicles. } \\
\text { Earthquake in } \\
\text { sea is a big } \\
\text { challenge. }\end{array}$ & $\begin{array}{l}\text { Proposed world } \\
\text { first SFT by } \\
\text { NORWAY } \\
\text { (NPRA) } \\
\text { Predicted cost } \\
\text { \$25 Billion }\end{array}$ \\
\hline
\end{tabular}

\section{- DISCUSSION}

In tunneling projects, it is essential to control and predict the ground surface settlements observed during and after the excavation process that may cause damage to the structures present on the earth surface.. Otherwise, project time and tunneling cost significantly increase due to damage to structures caused by the surface settlement that occurs above the bearable limits. Therefore, the tunnel construction methods need Tobe chosen and used very carefully. Also, deep understanding regarding the various aspects and issues related to these tunneling methods is very necessary. Improper use can lead to discrepant results and potential hazard if used in decision making. The selection of each tunnel construction method is done on the basis of their advantages, disadvantages and limitations.

Against this backdrop, the variable density tunnel boring machine is not just a further advancement of the convertible shield additionally an unequivocal development step. Variable density TBM can be very useful over other tunneling methods if utilized and handled properly. The idea unmistakably builds adaptability and security inside the tunnel and the machine is generally usable in variable (mixed) ground. For short range and 
small $\mathrm{km}$ passing with poor ground and geological condition, immersed tube tunneling is best type of construction technique.

\section{CONCLUSION}

Tunnels are constructed under high mountains and sea coming across the way. Both are necessary as per requirements. It depends on all kinds of things; local planning (does it fit the landscape), ground conditions, future planning of the surrounding area including use and ground levels, usage of the waterways below etc.

The practical engineering judgement during the excavation and construction of a tunnel should be applied according to the context and type of problem case encountered. Problems like muck conveyance or face pressure in variable ground conditions within the tunnel alignments require innovative and new tunneling technologies. In this age of advanced tunneling technology, tunneling method such as drill and blast, NATM, Cut-and-Cover, Jacked box, Slurry TBM, Earth Pressure Balance Machine and immersed tube tunnel or SFT may not meet requirements under certain tunnel project conditions concerning economic efficiency and safety any more.

\section{ACKNOWLEDGEMENT}

First of all we are thankful to respected principal Dr.Varsha Shah, Of RCOE, Mumbai and Prof.Avinash More (head of department) of Civil Branch for giving us a kind of approval to prepare and submit the project.

We also thank Prof.Manjari Bhattacharya for their guidance and continuous encouragement throughout the academic to see that this project rights to its target from its commencement to the completion.

We avail this opportunity to convey our sincere thanks to those who have directly or indirectly contributed to our project work and for the teaching us to see the silver lining in every Dark cloud.

\section{REFERENCES}

[1] Sharma, P. D. (2011). "Tunnel Construction Methods and their comparison." Retrieved 23 March 2016, from https://miningandblasting.wordpress.com.

[2] Ahmed, A. (1994). Analysis of deck road tunnels. Tunnelling and ground conditions. Proceedings of the international congress on tunnelling and ground conditions, Held Cairo, Egypt, 3-7 April 1994.

[3] J. Baber, \& L. Narvestad. Maintenance considerations for immersed tunnels, with particular reference to the Bjørvika Tunnel. In Proceedings of the Fifth Symposium on Strait Crossings, Trondheim, Norway, 2009.

[4] J. Baber, T. A. M. Salet, \& L. K. Lundberg. Øresund TunnelControl of early age

[5] Cracking. In Proceedings of the IABSE Colloqium on Tunne Structures, Stockholm, Sweden, pp. 175-180, 1998. ISBN 3-85748096-3.

[6] Schmidt B. (1969). 'Settlements and ground movements associated with tunnelling in soil'. Unpublished Ph.D. thesis, University of Illinois, Urbana-Champaign, IL.

[7] Wang, F., B. Gou and Y. Qin (2013). "Modeling tunneling-induced ground surface settlement development using a wavelet smooth relevance vector machine." Computers and Geotechnics 54: 125132.

[8] Abdallah, M. and M. Marzouk (2013). "Planning of tunneling projects using computer simulation and fuzzy decision making." Journal of Civil Engineering and Management 19(4): 591-607. 